\title{
4
}

\section{ACROSS THE DOORWAY: DEVELOPING POST-CRITICAL MUSEOLOGY FROM A CLOSED UNIVERSITY MUSEUM}

\author{
Erika Grasso and Gianluigi Mangiapane
}

The Museum of Anthropology and Ethnography of the University of Turin (MAET) is dealing with two main challenges: the problematic nature of its cultural heritage and its closure to the public. This chapter presents two museological experiences that offered the opportunity to face these challenges by focusing on alterity and its exbition. It is based on the reflections conducted by the museum staff in recent years regarding the accessibility of the MAET heritage and its representation of 'otherness.' The first section will retrace the MAET situation by pointing out that its closure made visible a concrete threshold between the heritage and the public. The doorway represents a challenge that connects the peculiar MAET experience to the recent theoretical approach in museology and cultural anthropology to material culture, museum and subjectivities. Therefore, the central sections of this contribution will address two case studies: A Piece About Us (2014) and Gelede. Our Yoruba Mothers (2018). They show how it is possible to open the doors of a closed museum and to exibit its challenging cultural heritage. The case studies presented in this chapter are part of the Museum staff's wider reflections initiated in preparation of the opening planned for 2026. While different in terms of design and results, the two experiments are grounded in a museum anthropology approach and were implemented by an ethnographic and participatory approach. The conclusions will underline how a closed museum can reinforce its relevance by taking into account the subjectivities that its heritage represents and by improving museological strategies grounded on the relationship between the institution and local agency and communities.

The MAET contains a cultural heritage consisting of both anthropological and ethnographic collections that represent humankind in its diversity and alterity (Grasso, 2020) and has been closed to the public since 1984. Its staff is involved both in research projects related to the history and meanings of collections and to new strategies to improve audience engagement and heritage enhancement. Given 
the wide variety of finds preserved and the closure situation, the MAET is committed to reflections on how to expand its audience and, at the same time, initiate processes that may involve and give voice to the subjectivities represented by the collections, especially the ethnographic ones.

The closed doors of the museum rooms symbolise a threshold that has been waiting to be crossed for a long time. It is a physical boundary that divides the museum from the society of which it is a product and that prevents the museum from being relevant in its social context (Simon, 2016). In the last decade, the MAET experimented with strategies to unlock its doors and to cross the threshold in order to build new and deep connections with people who potentially could self-identify with its heritage. In order to better handle the peculiar challenges faced by the Museum, professionals' practices and academic discourse have been integrated and new strategies have been implemented. Today the Museum faces the urgency to make its heritage accessible and to attract new audiences and, at the same time, to improve the most equitable and participatory strategies of representation of alterity and 'otherness.' Recently the doors of the MAET were opened for special events during which visitors were able to enter the rooms of the museum or, conversely, the MAET heritage was able to reach them outside the museum. During these occasions we explored how to find a balance between institutional and conservation requirements and the social role of a museum that holds multifaceted collections.

If the doorway divides the museum from its society and its public, is it possible to cross it? Can experimental strategies and design bring to light memories concealed by the heritage, sharing it with audiences who can identify with it? In answering these questions, this chapter addresses some fundamental issues related to the role of museums as places of heritage conservation and enhancement and as sites where identities and memories come into contact (Amselle, 2016). Moving from the present condition of a university anthropological museum (MAET), our chapter will show how academic discourse can enter into dialogue with museological practices so as to better handle the challenge of moving across the museum doorway and to overcome barriers that prevent it from being relevant and from improving public engagement. Although museums have often been understood as merely engaged in tradition and heritage preservation, it is essential to look at them as distributive networks in order to foster their social role (Hooper-Greenhill, 1992; Vergo, 1989). As highlighted by the seminal work Post-critical museology: Theory and practice in the art museum (Dewdney et al., 2013), museums are part of wide processes and relationships in which value travels along transmedial and transcultural lines. This approach fits the cultural anthropology efforts to question the one-way relationship between museums and cultures and to acknowledge how museums can be a 'contact zone' (Clifford, 1997). In this sense, as Jean Loup Amselle pointed out, museums are related to essential political issues and to the processes of re-appropriation of values by the different subjects involved in its activities, both recruited professionals and the public (Amselle, 2016). 


\section{The 'otherness' behind the door}

As for many museums (Ames, 1992; Coombes, 1994; Gosden \& Larson, 2007; O'Hanlon \& Welsch, 2000; Penny, 2002; Shelton, 2001a, 2001b; Stocking, 1985), the MAET holds ethnographic and anthropological collections which, due to their origins, are challenging and can be acknowledged as 'sensitive heritage' (Schorch, 2020, p. 1). Finds and artefacts are from social contexts and cultures that, due to the colonial trauma, have been impoverished in terms of historical memory and heritage. Ethnographic objects have been collected and often stolen from European colonies in Africa and South America, but also from Asia and Oceania. Like the anthropological finds from archaeological excavations in Egypt, they were not entrusted to local museums, but brought to Italy when this practise was still widespread. This corpus was formed between the 1910s and 1930s according to a racist approach and with political and ideological motivations. The scientific discourse was in fact committed as a support to the racial laws enacted in 1938 during the fascist dictatorship in Italy (Mangiapane \& Grasso, 2019). Therefore, the corpus was 'regarded, in turn, as laboratories for anthropological theorising, showcases of empire, and halls for the edification of the public' and the ethnographic museum 'fulfilled multiple functions and became the chief site through which knowledge of colonised peoples was both constructed and displayed' (Basu, 2012, pp. 371-372) as underlined also by Bernard Cohn in his seminal work Colonialism and its forms of knowledge (1996). Furthermore:

Within the dominant cultural-evolutionist paradigm late in the nineteenth century, for example, ethnographic artefacts acted as indices of the evolutionary status of different societies and provided a tantalising glimpse into Western society's own 'prehistoric' past [...]. A result of this was a continuing contiguity between ethnographic and archaeological collections in Western museums at a time when anthropology and archaeology were, as yet, indistinguishable academic disciplines

(Basu, 2012, p. 372).

When material culture represents 'otherness' it may be important to recognise these intrinsic problems and to narrate the present and past power relationships between 'cultures.' In fact, the processes of collection and exposure (or nonexposure) of the extra-European artistic and ethnographic heritage are never neutral (Karp \& Lavine, 1991). They are a symptom of the colonial relationship between Western society with what has been called the Global South. In this sense, MAET collections deserve to be viewed according to a biographical approach (Appadurai, 1986) and to be considered knowledge in a museum decolonisation process (Chambers et al., 2014). This involves a deep reflection on the relationships between the society of which the museum institution is a fruit and 'otherness' (Grasso, 2019). It also allows acknowledgement of the colonial 
memory and the power relations crystallised in the materiality of cultural heritage and latent in the museum institution and its deposits.

It is therefore necessary to face MAET history through reflections that are supported by a large and diverse literature that deals with assets and decolonisation (Chambers et al., 2014). The result of these analyses should then be translated into processes, activities and good practices. Considering that 'in museum studies and related fields, our sense is that the now-classic postcolonial critique of colonial museums and collecting is near exhaustion, and scholarship requires fresh frameworks and approaches in order to move beyond a reductionist analysis of this topic and to open up new angles on the two-way encounter of coloniser and colonised, objects and subjects, human and non-human' (Cameron \& McCarthy, 2015, p. 2), there is still a lot to do.

The objects included in the museum context are part of acquisition processes that often need to be reconstructed. In this sense, the research work is leading to a deeper awareness of the nature of the artefacts stored in the deposits. The trajectories undertaken by each object from the moment of its production to current time cross spaces and geographies. They have survived journeys, cultural and social upheavals that have charged them with dense and changeable meanings, dictated by imaginary and shared memories both in the production context and in the one in which they were first collected and then put into museums. Recognising the value, in some ways ambiguous, of artefacts and their immeasurable 'inbetween' nature (Basu, 2017, p. 2), entails a necessary review of the role of the museum institution as a space for preservation and enhancement of cultural heritage, but also as a space and place of representation of society in which it is inserted and those of which it preserves the material culture.

\section{Crossing the doorway}

A pivotal moment in the history of ethnological and anthropological collections was the transformation that has affected the international museum world from the 1980s onwards, starting with the Nouvelle museologie up to the most recent postcritical museology movements. According to these approaches, the museum must be an open space (Vergo, 1989) dedicated to the re-elaboration of memories and narratives that allows a better and more aware understanding of the present society and of the relations of power and inequality that characterise it. Post-critical museology considers museums 'as distributive networks in which value travels along transmedial and transcultural lines' (Dewdney et al., 2013, p. 1). It encourages museum professionals to move to a wider audience engagement in institutional life. It has allowed the public to cross the physical and cultural thresholds - the doorway. In this sense, the museum acquires a new social role in terms of social inclusion and/or exclusion (Sandell, 2003, p. 45), in the belief that art, like cultural heritage, is not neutral but can have a strong political and social role (Benjamin, 1936). 
The MAET is waiting for a permanent display accessible to the public that allows it to express new ways of thinking and 'showing' 'otherness' and the European society that has 'accumulated' objects and documents of the 'other worlds.' Meanwhile, it must necessarily face the challenge of making a 'closed' heritage accessible, through alternative ways to those of an 'open' museum. The museum, hidden behind closed doors, is trying to cross the threshold and reach the public in spaces and contexts in which a quite unknown heritage can finally be 'seen.' As we will see, a first step in this direction is the narration of 'otherness' through multiple forms. A further step across the thresholds is the reconstruction of the production contexts and collecting practices that involved everyday objects and artefacts produced by 'other' cultures. In this sense, the ethnographic collections offer a space for dialogue and reflection that is not only interesting, but in some ways necessary in order to recognise the memory of contacts with 'otherness' that for Italian society are not a novelty of the present. They have roots that stretch back in time and that are the foundation of the very constitution of the Italian national community.

The approach of cultural anthropology to heritage has allowed taking this path by introducing not only new ideas for theoretical reflection, but also new investigative tools. In particular, the ethnographic and participative method has put in the spotlight the ethnographic collections and the role of the museum that preserves the subjectivities (individual and collective) producing and accumulating 'other' material culture and giving them a voice. The reconstruction of the history of the collections makes it possible to trace the individual trajectories of the protagonists of the collection processes that include objects of affection, travel souvenirs and tangible documents of scientific research. A step towards restoring light and space to the layered memory on the objects is to enter into dialogue with the societies from which they themselves come.

\section{The first study case: the threshold and the project A Piece About Us}

Between 2008 and 2015, one of the priorities of the MAET projects was to involve those subjectivities that usually were not taken into account by MAET activities (Mangiapane et al., 2013; Pecci, 2019; Pecci \& Mangiapane, 2010). Of particular relevance was the project APAU: A piece about us (2014-2015), written by the museum anthropologist Anna Maria Pecci and created by two associations involved in cultural and cultural heritage enhancement initiatives: Associazione culturale Passages (Passages Association) and Giovani Musulmani d'Italia (Young Italian Muslims Association, GMI). The two partners chose to invite museum institutions, archives and libraries to collaborate in the project in order to involve the Library, Archive, Museum Circuit (LAM). This was a pivotal step since these institutions have 'commonalities of collecting in the creation and maintenance of the knowledge communities' (Hedstrom \& King, 2004), but totally different audiences. The Museum of Oriental Art (MAO), Palazzo Madama Civic 
Museum of Ancient Art, the MAET and the Historical Archive of the City of Turin and Turin Public Libraries were part of the partnership, chosen for the diversity of their heritage. The A Piece About Us project was funded by the banking foundation Compagnia San Paolo and by the CRT Banking Foundation.

The project aimed to facilitate audience engagement. The activities involved young people, including second-generation Italians, through participatory practices that moved from an initial analysis of the different partners' needs. Furthermore, 30 informants were selected through a public call and interview. The announcement was made in the youth centres of the city (e.g., the TYC: Turin Youth Centre, University halls, on notice boards and websites, and in libraries and bookshops). Due to the aims of the project, the selection of intended audiences was based on varied criteria: the interviews made it possible to select people from diversified backgrounds. The key informants were between the ages of 23 and 30 with different social and educational backgrounds and interests (e.g., theatre and art world, humanities education, etc.) but unified by the interest in cultural heritage, even when not occupied in cultural activities. Among the 28 participants, there were 8 men and 20 women, and 4 were second-generation Italians. Only one was a student; the others had finished their studies.

A training course enabled the participants to know the history and the cultural heritage held in the museums, archive and libraries and to re-interpret it according to a performative approach that could lead to a social action or to have a change of effect. This approach emerged as most effective in reaching and involving the young 'non-public' of the partner institutions. The results of the project and what was conceived and realised were presented as a tool of mediation that can connect museum collections and the public during exhibitions, meetings and a YouTube channel and social networks as well. More generally, the products were multiple and involved different expressive languages (theatrical performances, readings, dances and videos). This initiative acknowledged the cultural heritage as a creative inspiration: it showed how it can enable to conceive and realise theatrical performances and videos in a 'perspective of cultural empowerment and favoring the museum's social agency' (Pecci, 2019, p. 210).

Among the projects carried out in recent years by the MAET, A Piece About Us is the one most oriented to audience engagement (Bollo et al., 2017). Being grounded in a process of involvement of the public, it had a subsequent phase of achievement in which different methods were used to get in touch with the public and with young people under age 30 . APAU has in fact included a great variety of tools and approaches: expressive languages as a mediation instrument, active involvement through theatre workshops, participation in the planning of activities and the creation of expressive, artistic and creative contents (Da Milano \& Gariboldi, 2019).

During the course of the project, the various partners responded favourably to some participants' requests who explicitly showed interest in LGBTQ (Lesbian, Gay, Bisexual, Transgender, Queer) issues. Despite the important steps forward, in 
fact it seems that most of the cultural institutions still do very little to represent this community and tell its stories (Kendall, 2011), while in reality they might try to answer the question 'You can't tell LGBTQ stories where they don't exist. Or can you?' (Goodman, 2018, p. 71). Therefore, the participants devised new initiatives, called 'New paths,' where objects, books and documents involved did not necessarily belong to the LGBTQ world, yet they were useful for the purpose since they were able to talk about 'other' worlds. As the museologist Sian Goodman pointed out:

I feel strongly that those of us who work in heritage and arts have a responsibility to disrupt the biased narratives of the past and include more diverse stories which more people can connect with. History has been very kind to the straight, white male, and he has done pretty well off the back of it! But by repeating his account, we're never going to grasp the opportunity we have to be a part of broader cultural, political and social change.

(Goodman, 2018, p. 71)

Therefore, the MAET collections have been used in an inclusive way as a pretext to deal with these aspects. The fruits of this was a theatrical performance called Looking for Marilyn, staged at Casa Arcobaleno (Rainbow House) in Turin, and in the video performance Tribute to Marlene Dietrich by the actor Lorenzo Beatrice. This monologue was conceived by starting from some photographs of Marlene Dietrich conserved in the Historical Archive of the City of Turin. The life of this LGBTQ icon became the pretext to talk differently about the heritage through a queer point of view. Simultaneously, the reading of copies of medical records kept in the MAET archive (Beatrice, 2015) made it possible to denounce how in the 1930s, during the fascist period, homosexuals were considered mentally ill and interned in a mental hospital (Romano, 2020) The theatrical performance, using a comedy director and in the form of a 'murder mystery dinner,' staged and reinterpreted the heritage with a look that was far from institutional.

At the end of the performance, an evaluation was carried out through random interviews (six people per two shows and open-answer interviews). The public expressed enthusiasm seeing how these institutions, which are often perceived to be distant from their civil claims, had given full support to a clearly oriented path. To the question 'What are the strengths and weaknesses of the networking attitude initiative?' most replied that they appreciated the willingness of the museums to seek community issues in their heritage from an inclusive perspective but all interviewees suggested to propose the show beyond the LGBTQ+ circuit in order to share the community stories and points of reference to a wider public. Finally, it should be emphasised that there were no difficulties from the members of the Young Italian Muslims Association participating in the project in supporting these initiatives. 


\section{The second study case: the Our Yoruba Mothers exhibit}

A more recent attempt to cross the threshold of the museum's doors was made with the exhibition Gelede. Our Yoruba Mothers (2018), designed and set up as part of the event Turin. Towards an accessible city, and within the context of the European Year of Heritage. The exhibition project involved the museum staff, an anthropologist and video maker, a private collector and some informants belonging to the Yoruba community in Turin (Yoruba people are a broad ethnic community that historically inhabits the southwestern regions of Nigeria, Benin and Northern Togo). The choice of Gelede masks was dictated by the intuition that they could represent the MAET African heritage thanks to a display that enhanced its value of documenting the complexity of an 'other' culture and avoiding traps of exoticism and reification of 'otherness.' These aims were achieved by giving space and voice to subjects that recognised themselves as part of the culture the artefacts are from.

The collaboration with the Piedmont Centre of African Studies and with the Intercultural Centre of the City of Turin allowed the initiation of an intense dialogue with the Panafricando Association and, therefore, with some members of the Turin Yoruba community. The MAET staff coordinated all the activities related to the project, including the informants' recruitment and the process of data elaboration through visual material and texts. The encounter with the associations and with the Yoruba community allowed, in the first analysis, to introduce the museum to local African diasporic associations and, after long years of silence, to present the museum institution as an open meeting space, social agency and - more generally - a place for dialogue. Renato Capra was involved as a private collector and African art expert.

The design process moved from the need to deepen the knowledge on the MAET African ethnographic collection to which Gelede masks belong. The private collector and MAET experts' theoretical knowledge was integrated with the cultural and emic point of view of Yoruba informants. The result was a temporary exhibition in the main hall of the Luigi Einaudi Campus (C.L.E.) of the University of Turin. Display cases were positioned in the very core of the university campus. They showcased ten African masks accompanied by short captions and a couple of explanatory panels. Each showcase was accompanied by a QR code thanks to which visitors could access further information given by descriptive texts and videos uploaded on the MAET website.

The path that led to the inauguration of the exhibition developed through three fundamental hubs: the choice of the objects to display, the identification of the research methodology underlying the exhibition itinerary and, finally, the design of the expositive path. The project involved a dialogue between the museum institution and the Turin diasporic community. The subjects involved reflected on their own culture, both the one that produced the masks on display, and the one that collected them and transformed them into museum objects. On the one hand, heritage revealed its nature as a medium, helping to bring together 
different and distant sectors of society and, on the other, the museum revealed its nature of 'contact zone' (Clifford, 1997). Thanks to the collaboration between different subjects, the museum opened its doors and its ground became the site where different voices and different points of view came together. The display was the first step on the way to better mutual understanding between the subjects which are represented in the museum rooms.

The exhibition displayed the MAET's helmet masks that belong to the Yoruba ritual complex and that were collected in Nigeria as travel souvenirs in the first half of the twentieth century according to ways that are waiting to be clarified. Gelede masks are worn by male performers during festivals which honour the women of the community (living and dead) and have the function to educate and entertain at the same time (Lawal, 1996). In order to enrich the narrative and expository path, MAET artefacts and the masks from the private collection made it possible to connect different acquisition trajectories and practices of collecting.

The project involved different subjects who collaborated with the museum staff in the research and in the production of textual and multimedia contents. The method chosen to achieve the project's goals was that of participatory ethnography and involved some Turin Yoruba residents who proved to be open to dialogue. They were selected with help from the diasporic association Panafricando. In particular, among the Yoruba community five informants were involved and accepted to be interviewed. They contributed to the process of knowledge production regarding the artefacts and to compile the captions, which later took the form of videos shared with the public. Anthropological knowledge was integrated with the informants' emic point of view, that is, the gaze on heritage from their way of perceiving and categorising the world according to their cultural background. The 'participatory' research on the heritage influenced the way in which the project participants imagined the exhibition path. The informants were free to give their own explanation and meanings to the objects, while data and information conveyed by the display panels and captions were limited to a minimum. The result was a simple setup that did not require structured design and the intervention of architects or designers. The voices of the diasporic community, in fact, had a central and sufficient role in the enhancement of the heritage and in making its multiple meanings emerge.

The dialogue with Renato Capra was interesting and fruitful. Often, private collectors have an exotic insight into African material culture that transcends the cultural and emic meanings of artefacts. This type of gaze is grounded in the Western perception of alterity - and in particular of Africa (Mudimbe, 1988) - and focusses on the alleged originality of the objects and their value on the ethnic art market. In fact, as highlighted by Ivan Bargna:

[...] today the consumption of exotica receives a boost from ethno-tourism on the one hand, with its search of 'authenticity' that bears traces of our ambiguous attraction to the 'dark continent', and on the other hand the 
vintage trend that has brought back into fashion, among other veins of nostalgia, a sanitised version of colonialism.

(Bargna E Parodi da Passano, 2010, p. 29)

The involvement of a private collector made it possible to question the motivations of the practice of collecting 'ethnic' artefacts that are related to collectors' individual trajectories, to their feelings of memory and forgetting (Bargna \& Parodi da Passano, 2010, p. 23) and to their experiences of identification with the object (Derlon \& Jeudy-Ballini, 2008, p. 192). In particular, the evolution of the relation between Renato Capra, the museum staff and the anthropologist video maker was exemplary. Initially, in fact, the dialogue between these three subjects was far from easy and was affected by different and apparently irreconcilable positions.

The researchers and anthropologists' approach focussed on a diachronic and synchronic contextualisation, aimed at bringing out the present artefacts' meanings and not only their 'traditional' or artistic value. They applied a biographical approach to the material culture (Kopytoff, 1986) that takes into account the social (Appadurai, 1986) and relational nature of objects (Miller, 2005). The anthropologists wished to give space and voice to the Yoruba interviewed who spoke of active objects, rich in meanings that go beyond the masks' artistic quality. In a very interesting way, they expressed surprise seeing African artefacts in an Italian museum. Seeing the masks, active and meaningful objects that refer to the social and spiritual experience of today's Yorubas, aroused their amazement: 'Why are there these objects here? What do these Europeans do with them?' exclaimed a young Yoruba shortly before an interview. The act of collecting artefacts of artistic value met the emic feelings of Yorubas who see the masks as documents of their heritage and, in a much stronger way, as objects of daily use and, above all, of value because ritually 'active.'

One summer afternoon, the staff and the video maker were ready to shoot the first interview with a young Yoruba lady, and the MAET masks were placed on a table. The idea was to frame them or to use them as an evocative background to the video. The young woman, however, was visibly uncomfortable. After a few hesitations she said: 'I won't say anything if the masks are there. In their presence I don't speak. They are powerful objects, I don't want to joke about these things.' The negotiation between the subjects involved was related to two different types of identification with the objects. The first, that of the collector, had to do with the very reasons why the masks are thoughtful pieces of art and with the personal commitment of Renato Capra himself in the study and care of the objects. The second was proper to the comprehension of the objects as 'active' elements of Yoruba culture and, therefore, bearers of complex meanings. The aim of giving voice to both of these visions was achieved through the involvement of Renato Capra in the composition of short guides to the exhibition which offered the public a 'formal' knowledge of Gelede masks. The guide was integrated with short videos in which Yoruba informants offered their own comprehension of the masks 
and of their cultural heritage. Therefore, two different tools were available to visitors offering two ways of 'reading' the exhibition path: on the one hand, the short guide and, on the other, the videos uploaded on the MAET YouTube channel which could be accessed via a QR code located under each showcase.

The participatory approach and the methods offered by visual anthropology allowed the subjects involved to cross the museum doorway. The MAET became a set for video interviews during which the informants offered a definition and a narrative of the masks and their own culture. Through the words of the Yoruba, different points of view emerged regarding the masks. These artefacts are far from works of 'primitive art' or dumb documents of another culture, but rather living elements of the contemporaneity of the community, even in its own diasporic dimension. Gelede masks emerged from the museum showcases and from the rooms of the private house in which they have been preserved for years, not only in a physical sense but also in a wider metaphorical sense. The present time, used by the interviewees, brought to life intelligible meanings of the Yoruba. The narrative from an emic point of view, therefore, allowed presenting the heritage by giving a voice to those who it represents. This involved, on the one hand, the overcoming of reifying definitions of the culture of others, and on the other, the connection of scientific and anthropological knowledge with the Yoruba view of their own culture and of Gelede masquerades. If the panels accompanying the display offered an overview of these themes, the videos to which the public had access through a $\mathrm{QR}$ code allowed them to go deeper into some elements thanks to the interviewees' voices. Through real multimedia captions, the video interviews gave an opportunity to relocate the masks in a context where different subjectivities could be recognised.

Two events linked to the exhibition allowed the academic world to meet some collectors of African art, the Yoruba and some exponents of the Turin African cultural associations. In fact, the inauguration saw the participation of numerous members of the Nigerian community, which appears to be very numerous in the city and is composed of both those present in Italy for some time and those who came more recently and are currently involved in the processes of seeking political asylum. The Main Hall of the university campus that hosted the exhibition was the scene of unexpected interactions and a real meeting place between students, researchers and the migrant population. The feedbacks collected in this regard document an interest for other cultures that before had rarely been expressed. Actually, 'otherness' populates the streets of the city and of the country and too often are the subject of reified and exotic narratives. During the inauguration, the representatives of the 'other' culture had the opportunity to talk, offering a different, positive and open look concerning Nigeria and its cultures.

The attention to European and non-European ethnographic collections preserved by the MAET has meant gaining awareness, on the one hand, of the need to bring out cultural heritage and make this heritage accessible, and on the other, the urgency of a profound reflection on the contexts of production of the objects and the events that led to the formation of the museum collections. This need for 
further investigation became indispensable also because of the report on the restitution that was published in France by Sarr and Savoy (2018) almost simultaneously with the exhibition.

\section{Conclusion}

The particular situation of the MAET invites a rethinking of museum practices into more experimental modes and a reconceptualisation of the dialogue between academic discourse and museology. Thanks to targeted projects, the heritage had the opportunity to cross the doors and the museum could widen its audience. The two cases made it possible to reach an audience otherwise difficult to involve and to overcome the idea that the museum institution is only a site for the conservation of a heritage. The social role of the museum was thus somehow addressed and sustained, and the physical and symbolic thresholds that divide the museum rooms from the outside world were at least partly overcome.

The establishment of relationships and dialogues between different institutions and between institutions and civil society allowed the opening of the museum's doors and gave an opportunity to not only rethink heritage in a more shared way, but also to lay the foundations for their future. In this sense, the museum's legacy is to have found an institutional network to work with in the future. It is made up of institutions, but above all it connects experts and academics with the subjectivities that the museum represents through its heritage. In particular, the collaboration between different professional figures emerged fruitful and allowed the achievement of the museum's mission.

The priority now is to systematise what has been achieved and to integrate practices already tested with participatory and dialogical ones: it appears essential to activate good practices of sharing and further research regarding the heritage and a possible audience. Therefore, these experiences like APAU and Gelede. Our Yoruba Mothers can be a good basis to foresee exhibitions that take into account recent theoretical reflections on ethnographic collections. According to the MAET experience, they will have a certain weight in its future choices and will lead the MAET to imagine, with the help of the scientific committee but also of architects and designers, a display that takes into account three fundamental points that can be useful to go beyond its doors. First, the approach offered by museum anthropology and participatory ethnography methods will make it possible to recognise the power relations and the need for decolonisation typical of the nature of the museum institution as it has been thought up to now. In this case, the doors would finally open to subjectivities which are often excluded from the museum's world and which, however, are often the subject of narratives within it. Second, it will be essential to remember the problematic nature of MAET collections which are bearers of critical memories and unfair relationships between cultures. In this case, crossing the threshold will mean finding the opportunity of turning the critical nature of collections into an opportunity to make them more inclusive. Third, we need to remember that the museum is a political space linked to 
memories, a diachronic and synchronic gaze on the history and present of the MAET, will be essential to open the doors and reread the heritage according to contemporary contexts and aims.

\section{Bibliography}

Ames, M. M. (1992). Cannibal tours and glass boxes. University of British Columbia Press. Amselle, J. L. (2016). Le museé exposé. Editions Ligne.

Appadurai, A. (Ed.). (1986). The social life of things: Commodities in cultural perspective. Cambridge University Press.

Bargna, I., \& Parodi da Passano, G. (2010). Introduction: The wonders of Africa. In I. Bargna \& G. Parodi da Passano (Eds.), The wonders of Africa: African arts in Italian collections (pp. 23-42). Silvana Editoriale.

Basu, P. (2012). Material culture: Ancestries and trajectories in material culture studies. In J. G. Carrier \& D. B. Gewertz (Eds.), Handbook of sociocultural anthropology (pp. 370-390). Bloomsbury.

Basu, P. (Ed.). (2017). The inbetweeness of things: Materializing, mediation and movement between Worlds. Bloomsbury Academic.

Beatrice, L. (2015, May 18). Omaggio a Marlene Dietrich (Tribute to Marlene Dietrich). [video]. https://www.youtube.com/watch?v=6ig3ywKP250

Benjamin, W. (1936). Das Kunstwerk im Zeitalter seiner technischen Reproduzierbarkeit. Suhrkamp.

Bollo, A., Da Milano, C., Gariboldi, A., \& Torch, C. (2017). Study on audience development: How to place audiences at the centre of cultural organisations. European Commission.

Cameron, F., \& McCarthy, C. (2015). Museum and Society special issue: Museum, field, colony: Collecting, displaying and governing people and things. Museum \& Society, 13(1), 1-6.

Chambers, I., De Angelis, A., Ianniciello, C., \& Oranona, M. (2014). The postcolonial museum: The arts of memory and the pressures of history. Ashgate Publishing Limited.

Clifford, J. (1997). Routes: Travel and translation in the late twentieth century. Harvard University Press.

Cohn, B. S. (1996). Colonialism and its forms of knowledge. Princeton University Press.

Coombes, A. E. (1994). Reinventing Africa. Yale University Press.

Da Milano, C., \& Gariboldi, A. (2019). Audience development. Franco Angeli Ed.

Derlon, B., \& Jeudy-Ballini, M. (2008). La passion de l'art primitive: Enquête sur les collectionneurs. Gallimard.

Dewdney, A., Dibosa, D., \& Walsh, V. (2013). Post-critical museology. Theory and practice in the art museum. Routledge.

Goodman, S. (2018). You can't tell LGBTQ stories where they don't exist: Or can you? In R. Sandell, R. Lennon, \& M. Smith (Eds.), Prejudice and pride: LGBTQ heritage and its contemporary implications (pp. 71-75). School of Museum Studies, University of Leicester.

Gosden, C., \& Larson, F. (2007). Knowing things. Oxford University Press.

Grasso, E. (2019). Strade, sguardi, voci: Fondi fotografici inediti e memoria coloniali dall'archivio del Museo di Antropologia ed Etnografia dell'Università di Torino. RootsERoutes. Research on Visual Cultures, 9(29). https://www.roots-routes.org/stradesguardi-voci-fondi-fotografici-inediti-memoria-coloniale-dallarchivio-del-maet-erikagrasso/

Grasso, E. (2020). Cultura materiale e alterità: Il caso del Museo di Antropologia ed Etnografia di Torino, Voci (in press). 
Hedstrom, M., \& King, J. L. (2004). On the LAM: Library, archive, and museum collections in the creation and maintenance of knowledge communities. Mapping innovation: Six depth studies. http://www.oecd.org/dataoecd/59/63/32126054.pdf

Hooper-Greenhill, E. (1992). Museums and the shaping of knowledge. Routledge.

Karp, I., \& Lavine, S. D. (Eds.). (1991). Exhibiting cultures: The poetics and politics of museum display. Smithsonian Institution Press.

Kendall, G. (2011). Why are museums so scared of LGBT stories? Museum Association. http://www.museumsassociation.org/news/04102011-why-are-museums-scared-oflgbt-stories

Kopytoff, I. (1986). The cultural biography of things: Commoditization as process. In A. Appadurai (Ed.), The social life of things: Commodities in cultural perspective (pp. 64-91). Cambridge University Press.

Lawal, B. (1996). The Gèlèdé spectacle: Art, gender, and social harmony in an African culture. University of Washington Press.

Mangiapane, G., \& Grasso E. (2019). Il patrimonio, i non detti e il silenzio: le storie del MAET. RootsERoutes: Research on Visual Cultures, 9(30). https://www.roots-routes.org/ patrimonio-non-detti-silenzio-le-storie-del-maet-gianluigi-mangiapane-erika-grasso/

Mangiapane, G., Pecci, A. M., \& Porcellana, V. (Eds.). (2013). Arte dei margini: Collezioni di Art Brut, creatività relazionale, educazione alla differenza. Franco Angeli.

Miller, D. (2005). Materiality: An introduction. In D. Miller (Ed.), Materiality (pp. 1-50). Duke University Press.

Mudimbe, V. Y. (1988). The invention of Africa: Philosophy and the order of knowledge. Indiana University Press.

O'Hanlon, M., \& Welsch, R. L. (Eds.). (2000). Hunting the gatherers. Berghahn Books.

Pecci, A. M. (2019). Sharing authority: The art of making a difference. In V. Golding \& J. Walklate (Eds.), Museums and communities: Diversity, dialogue and collaboration in an age of migration (pp. 204-215). Scholars Publishing.

Pecci, A. M., \& Mangiapane, G. (2010). Expographic storytelling: The Museum of Anthropology and Ethnography of the University of Turin as a field of dialogic representation. The International Journal of the Inclusive Museum, 3(1), 141-153.

Penny, H. G. (2002). Objects of culture. University of North Carolina Press.

Romano, G. (2020). Il caso di G: La patologizzazione dell'omosessualità nell'Italia fascista. Edizioni ETS.

Sandell, R. (2003). Social inclusion, the museum and the dynamics of sectoral change. Museum and Society, 1(1), 45-62.

Sarr, F., \& Savoy, B. (2018). Restituer le patrimoine africain: Vers une nouvelle éthique relationnelle. Seuil Ed.

Schorch, P. (2020). Sensitive heritage: Ethnographic museums, provenance research, and the potentialities of restitutions. Museum $\mathcal{E}$ Society, 18(1), 1-5. https://epub.ub.uni-muenchen.de/ 72084/1/3459-9133-1-PB.pdf.

Shelton, A. (Ed.). (2001a). Collectors: Expressions of self and other. Horniman Museum and Gardens.

Shelton, A. (Ed.). (2001b). Collectors: Individuals and institutions. Horniman Museum and Gardens.

Simon, N. (2016). The art of relevance. Museum 2.0.

Stocking, G. W. (Ed.). (1985). Objects and others. University of Wisconsin Press.

Vergo, P. (1989). The new museology. Reaktion Books. 